\title{
Are Results of Surgical Treatment for Calcaneal Fractures better than Nonoperative Treatment?
}

\author{
${ }^{1}$ Mandeep S Dhillon, ${ }^{2}$ Nitesh Gahlot \\ This paper was awarded the Ram Janam Sulakshana Medal for best paper at IFASCON 2013, Gurgaon, Haryana, India
}

\begin{abstract}
The methods of treatment of displaced intra-articular calcaneal fractures (DIACFs) have always been surrounded by controversies, whether operative treatment is better or conservative. Some randomized controlled trials (RCTs) have been published comparing the operative vs conservative management options for DIACFs, but the conclusions are varied, with some of them supporting operative treatment while others showing equivocal results. To get some clarity on this subject, we reviewed 9 RCTs and 4 meta-analyses to evaluate the evidence that was present for both operative and nonoperative methods of management. Most studies report equivocal outcomes of operatively and nonoperatively managed DIACFs when looked at; however on stratification of groups, the evidence seemingly points towards better functional results in the operated patients who do not develop a complication, but poorer outcomes in patients with more severe injury patterns (higher Sanders' Type). Complications were associated with both groups; no differentiation between closed and open fractures is made in most studies, leading to slightly higher rate of complications in the operated group (probably due to open cases inclusion); nevertheless the difference was not found significant. Despite a high level of interest in calcaneal fractures, the current evidence in published literature does not support a specific management protocol for DIACFs, although detailed analysis points to importance of patient selection, surgeon experience and soft tissue status. As of today, there is a need for larger randomized trials, which should also clarify the role of extensile approach vis a vis Minimally Invasive Surgery, to address this question and bring out a conclusive answer.
\end{abstract}

Keywords: Calcaneal fracture, Operative management, Displaced intra-articular calcaneal fractures (DIACFs), Randomized controlled trials, Meta-analysis.

How to cite this article: Dhillon MS, Gahlot N. Are Results of Surgical Treatment for Calcaneal Fractures better than Nonoperative Treatment? J Foot Ankle Surg (Asia-Pacific) 2014; $1(1): 17-23$.

Source of support: Nil

Conflict of interest: None

\section{INTRODUCTION}

The methods of treatment of calcaneus fractures have always been surrounded by controversies. Displaced intra-articular

\footnotetext{
${ }^{1}$ Professor, ${ }^{2}$ Senior Resident

1,2 Department of Orthopedics, Postgraduate Institute of Medical Education and Research, Chandigarh, India
}

Corresponding Author: Mandeep S Dhillon, Professor Department of Orthopedics, 1027, Sector-24B, Chandigarh India, e-mail: drdhillon@gmail.com calcaneal fractures (DIACFs) are the most confusing, as many times these are not specifically focused on when discussing calcaneal fracture treatment options. Over the years orthopedic surgeons have moved from nonoperative conservative management ${ }^{1,2}$ of displaced calcaneus fractures to operative interventions ${ }^{3-6}$ designed to give better reductions and early mobilization. However, the initial enthusiasm of operative treatment started to fade as the soft tissue complications $^{7}$ related to extensile operative approaches started arising. Other options for management were explored, mainly due to lack of any solid literature evidence supporting any single treatment modality. Some randomized controlled trials (RCTs) were published comparing the operative vs conservative management options for DIACFs, looking at outcome measures and associated complications. However, no specific conclusions can be drawn, as the number of such RCTs is limited, and the published conclusions are varied, with some of them supporting operative treatment ${ }^{7-10}$ while others showing equivocal results. ${ }^{11-14}$ In the present paper we have tried to evaluate the available literature and find out which treatment modality may give better results in DIACFs, with the current levels of evidence and understanding of operative protocols.

\section{MATERIALS AND METHODS}

In this paper, we have focused on the RCTs and metaanalysis previously published comparing the operative $v S$ nonoperative treatment modalities for DIACFs. This was done as both RCTs and meta-analysis provide us with the highest level of evidence. A detailed search was done using the keywords: 'displaced intra-articular calcaneal fracture, displaced intra-articular fracture of the calcaneus, operation, nonoperation, surgery, nonsurgery, conservative treatment, randomized controlled trials, clinical controlled trials, controlled trials and meta-analysis', across various databases viz Cochrane database of systematic reviews and controlled trials, PubMed, ovid medline, Embase. The nonrandomized studies were excluded as they tend to have heterogeneity in outcome measures and usually have overestimation of the treatment effects. After a thorough search and review of the medical literature, we found 9 RCTs and 4 meta-analysis studies comparing the operative $v s$ nonoperative method of treatment of DIACFs. 
The earliest RCT was done in 1993 and the latest was published in 2013; the largest and most quoted study was done in Canada by Buckley et $\mathrm{al}^{11}$ in 2002, looking at 424 patients and comparing functional outcomes. The same data of these 424 patients' data was also evaluated by Howard et $\mathrm{al}^{7}$ in 2003 , to compare the complications in both treatment groups. Overall four meta-analyses have been done on this problem to date; the largest was done in 2012 by Jiang et $a 1^{15}$ comparing data from 10 studies with a total of 891 participants.

\section{OBSERVATIONS}

Our literature search yielded 9 RCTs, which compared the operative $v s$ nonoperative treatment options for DIACFs (Table 1). Earliest RCT was done by Parmar et $\mathrm{al}^{14}$ who enrolled 56 DIACFs for randomization. They reported that among the conservatively managed cases, undisplaced fractures had slightly better results than displaced fractures, but there was no significant difference between the operated and nonoperated groups in outcome. The authors also found that patients had more pain after displaced fractures rather than undisplaced fractures, and the operative treatment of subtalar joint was less likely to improve the outcome over conservative treatment. ${ }^{14}$ Interestingly, another RCT done on 24 patients by O'Farrell et al and published in the same year, recommended plating for the DIACFs through a lateral approach in patients under 40 years of age. ${ }^{9}$ They found out that the operated cases had significantly longer walking distances, lesser shoe modifications, better subtalar joint movements, partial or full restoration of Böhler's angle and a higher percentage of them returned to work.

The first prospective, randomized trial to demonstrate the superior results operative treatment as compared with nonoperative treatment was done by Thordarson et al ${ }^{10}$ in 1996. These authors randomized 30 patients and used a functional scoring system of 0-100 points which was developed based upon the responses to an outcome assessment questionnaire. The operated group fared significantly better $(\mathrm{p}<0.01)$ on functional scoring, and had more subtalar joint movements and less pain as compared to the conservatively managed cases. Two more studies by Howard et $\mathrm{al}^{7}$ and Nouraei et $\mathrm{al}^{8}$ subsequently also reported superior functional results in operated DIACFs fractures. Howard et al used the SF36 (Short form 36) and visual analog scale (VAS) scoring to assess functional outcomes and reported better results in the operated group, but the difference was not statistically significant. On the other hand, they also observed more complications in the operated group and noted more problems in Sanders type 4 fractures, as well as in patients receiving Workers' compensation. ${ }^{7}$ In 2011, Nouraei et al randomized 72 patients for operative and nonoperative groups and assessed outcomes using functional score based on Kerr's meta-analysis and pain scoring. Their results showed favorable outcomes in the operated group in terms of reduced pain $(p=0.001)$, swelling $(p=0.001)$, increased range of motion of the joints $(p=0.001)$ and decreased late osteoarthritis $(p=0.22)$. The authors recommend ORIF for DIACFs but in absence of open fracture, severe osteoporosis, or comminution and poor general condition. ${ }^{8}$

In 2002, the largest RCT was published by Buckley et al, ${ }^{11}$ enrolling 424 DIACFs patients, 206 operated and 218 conservatively managed after randomization. Outcome scoring, done by SF-36 and VAS score, found no significant difference between the two groups; but when the results were stratified, certain subgroups showed better results with operative treatment viz females, young males, patients without workers' compensation and less workload, fractures with increased Bohler's angle and a single undisplaced Intra-articular fracture. ${ }^{11}$ The SF-36 and VAS scores were again used by Dooley et al ${ }^{12}$ and Agren et $\mathrm{al}^{16}$ as outcome measures, latter study also used the AOFAS (American Orthopaedic Foot and Ankle Society hindfoot scale) score and OM (Olerud Mollander) score to compare the DIACFs outcomes. Both the studies found no significant difference in the above scores when the operated DIACFs were compared with the nonoperated ones, and the AOFAS score and OM score were also similar. ${ }^{16}$ However, both the studies reported higher rates of subtalar arthritis and subsequent arthrodesis in the nonoperated group. Ibrahim et a ${ }^{13}$ also reported similar outcomes in operated and nonoperated randomized groups, but they used different scores viz AOFAS, foot function index (FFI) and calcaneal fracture score (CFS) for clinical assessment and, Böhler's angle and calcaneal height for radiological outcome assessment. This study has the longest follow-up period of 15 years among all RCTs. ${ }^{13}$

Looking at the above RCTs, it is clear that still there no consensus regarding which treatment modality is better suited for DIACFs as a group. Different results come forward with every RCT done on this topic, mostly due to the use of different scoring systems, variable sample size and different follow-up periods. To get the overall picture and to find specifics answer to this question, some meta-analyses were done to statistically assess the results of these studies combined. Our literature search found 4 meta-analyses in the medical databases, which had chief inclusion criteria as 'RCTs comparing operative $v s$ nonoperative treatment of DIACFs' (Table 2).

The earliest meta-analysis was done by Randle et a ${ }^{17}$ who pooled data from 6 RCTs done on DIACFs. They reported that although the operated patients had better 
Table 1: RCTs done comparing operative vs conservative treatment for DIACFs

\begin{tabular}{|c|c|c|c|c|c|}
\hline $\begin{array}{l}\text { SI. Authors' } \\
\text { No }\end{array}$ & $\begin{array}{l}\text { No. of patients } \\
\text { (Total/ } \\
\text { operative/ } \\
\text { nonoperative) }\end{array}$ & $\begin{array}{l}\text { Study } \\
\text { type }\end{array}$ & Outcome measures & Follow-up & Conclusion \\
\hline \multirow[t]{3}{*}{$\begin{array}{l}\text { 1. Agren et al }{ }^{16} \\
(2013)\end{array}$} & \multirow[t]{3}{*}{$82 / 42 / 40$} & \multirow[t]{3}{*}{ RCT } & \multirow{3}{*}{$\begin{array}{l}\text { VAS } \\
\text { SF-36 form } \\
\text { AOFAS scale } \\
\text { OM scale }\end{array}$} & \multirow{3}{*}{$\begin{array}{l}1 \text { year } \\
(n=76) \\
8 \text { to } 12 \text { years } \\
(n=58)\end{array}$} & $\begin{array}{l}\text { Outcome of operative and non- } \\
\text { operative group at } 1 \text { year were } \\
\text { same }\end{array}$ \\
\hline & & & & & $\begin{array}{l}\text { At } 8 \text { to } 12 \text { years follow-up } \\
\text { outcome of operative group } \\
\text { was better }\end{array}$ \\
\hline & & & & & $\begin{array}{l}\text { Decreased rate of subtalar } \\
\text { arthritis in operative group }\end{array}$ \\
\hline $\begin{array}{l}\text { 2. Nouraei et } \mathrm{al}^{8} \\
(2011)\end{array}$ & $61 / 31 / 30$ & $\mathrm{RCT}$ & $\begin{array}{l}\text { Functional scoring } \\
\text { based on Kerr's } \\
\text { meta-analysis and } \\
\text { pain scoring }\end{array}$ & 1 year & $\begin{array}{l}\text { ORIFpreferredinyoungandmiddle } \\
\text { aged patients with Sander's } \\
\text { type II and III calcaneal fracture, } \\
\text { mild comminution due to minor } \\
\text { trauma, without soft tissue } \\
\text { injuries }\end{array}$ \\
\hline \multirow[t]{3}{*}{$\begin{array}{l}\text { 3. Ibrahim et } \mathrm{al}^{13} \\
(2007)\end{array}$} & \multirow[t]{3}{*}{$26 / 15 / 11$} & \multirow[t]{3}{*}{$\mathrm{RCT}$} & $\begin{array}{l}\text { AOFAS } \\
\text { FFI }\end{array}$ & \multirow[t]{3}{*}{15 years } & $\begin{array}{l}\text { No correlation between Bohler's } \\
\text { angle and outcome }\end{array}$ \\
\hline & & & CFS & & \\
\hline & & & $\begin{array}{l}\text { Bohler's angle } \\
\text { Calcaneal height } \\
\text { OA grade }\end{array}$ & & $\begin{array}{l}\text { Outcome of operative and non- } \\
\text { operative group at } 15 \text { years } \\
\text { were same }\end{array}$ \\
\hline \multirow[t]{2}{*}{$\begin{array}{l}\text { 4. Dooley et } \mathrm{al}^{12} \\
\text { (2004) }\end{array}$} & \multirow[t]{2}{*}{$\begin{array}{l}\text { Total }(47) \\
\text { Operative } \\
\text { Nonoperative }\end{array}$} & \multirow[t]{2}{*}{$\mathrm{RCT}$} & \multirow[t]{2}{*}{$\begin{array}{l}\text { Bohler's angle and } \\
\text { subtalar range of } \\
\text { motion, SF-36 VAS }\end{array}$} & & $\begin{array}{l}\text { Surgical intervention did not } \\
\text { significantly affect subjective } \\
\text { patient outcome as measured by } \\
\text { either SF-36 or the VAS }\end{array}$ \\
\hline & & & & & $\begin{array}{l}\text { Those who were treated non- } \\
\text { operatively were significantly } \\
\text { more likely to require late subtalar } \\
\text { arthrodesis }\end{array}$ \\
\hline \multirow[t]{4}{*}{$\begin{array}{l}\text { 5. Howard et } \mathrm{al}^{7} \\
(2003)\end{array}$} & \multirow[t]{4}{*}{$424 / 206 / 218$} & \multirow[t]{4}{*}{$\mathrm{RCT}$} & \multirow[t]{4}{*}{$\begin{array}{l}\text { SF-36 } \\
\text { VAS }\end{array}$} & \multirow{4}{*}{$\begin{array}{l}2 \text { to } 8 \text { years } \\
\text { (average, } \\
3 \text { years) }\end{array}$} & $\begin{array}{l}\text { More complications in sanders } \\
\text { grade } 4 \text { and WCB group }\end{array}$ \\
\hline & & & & & $\begin{array}{l}\text { Better outcomes in operative } \\
\text { group but difference not signi- } \\
\text { ficant }\end{array}$ \\
\hline & & & & & $\begin{array}{l}\text { But more complication rates in } \\
\text { operated group (wound related) }\end{array}$ \\
\hline & & & & & $\begin{array}{l}\text { Complications were seen regard- } \\
\text { less of management strategy }\end{array}$ \\
\hline \multirow[t]{2}{*}{$\begin{array}{l}\text { 6. Buckley et } a^{11} \\
(2002)\end{array}$} & \multirow[t]{2}{*}{$424 / 206 / 218$} & \multirow[t]{2}{*}{ RCT } & \multirow[t]{2}{*}{$\begin{array}{l}\text { SF-36 } \\
\text { VAS }\end{array}$} & \multirow{2}{*}{$\begin{array}{l}2 \text { to } 8 \text { years } \\
\text { (average, } \\
3 \text { years) }\end{array}$} & $\begin{array}{l}\text { Same outcome of operative and } \\
\text { nonoperative group }\end{array}$ \\
\hline & & & & & $\begin{array}{l}\text { Females, patients withoutworkers } \\
\text { compensation, young males, } \\
\text { increased Bohler's angle, less } \\
\text { workload, single undisplaced } \\
\text { Intra-articular fractures had better } \\
\text { results }\end{array}$ \\
\hline $\begin{array}{l}\text { 7. Thordarson } \\
\text { et } \mathrm{al}^{10}(1996)\end{array}$ & $30 / 16 / 14$ & $\mathrm{RCT}$ & $\begin{array}{l}\text { A functional scoring } \\
\text { system of } 0-100 \\
\text { points was developed } \\
\text { based upon the } \\
\text { responses to an } \\
\text { outcome assessment } \\
\text { questionnaire }\end{array}$ & $\begin{array}{l}15 \text { operative } \\
\text { (17 months) } \\
11 \text { non- } \\
\text { operative } \\
\text { (14 months) }\end{array}$ & $\begin{array}{l}\text { First prospective, randomized } \\
\text { trial to demonstrate the superior } \\
\text { results of current operative } \\
\text { treatment with early mobilization } \\
\text { compared with nonoperative } \\
\text { treatment }\end{array}$ \\
\hline
\end{tabular}




\begin{tabular}{|c|c|c|c|c|c|c|}
\hline \multicolumn{7}{|c|}{ Contd. } \\
\hline \multirow[t]{4}{*}{8.} & $\begin{array}{l}\text { Parmar et al }{ }^{14} \\
\text { (1993) }\end{array}$ & $56 / 25 / 31$ & RCT & $\begin{array}{l}\text { History and clinical } \\
\text { examination } \\
\text { (no specific score) }\end{array}$ & 23 months & $\begin{array}{l}\text { No significant difference between } \\
\text { the operated and nonoperated } \\
\text { groups in outcome }\end{array}$ \\
\hline & & & & & & $\begin{array}{l}\text { Small differences between out- } \\
\text { come of displaced and undis- } \\
\text { placed fractures which were } \\
\text { treated closed }\end{array}$ \\
\hline & & & & & & $\begin{array}{l}\text { Operative treatment of subtalar } \\
\text { joint not likely to improve outcome } \\
\text { over conservative treatment }\end{array}$ \\
\hline & & & & & & $\begin{array}{l}\text { More pain after displaced frac- } \\
\text { tures than undisplaced fractures }\end{array}$ \\
\hline 9. & $\begin{array}{l}\text { O'Farrell et al }{ }^{9} \\
(1993)\end{array}$ & $24 / 12 / 12$ & $\mathrm{RCT}$ & $\begin{array}{l}\text { Assessed on eight } \\
\text { parameters like return } \\
\text { to work, walking } \\
\text { distance, shoe size, } \\
\text { subtalar motion, etc. }\end{array}$ & 15 months & $\begin{array}{l}\text { Recommend plating (ORIF) } \\
\text { of displaced intra-articular os } \\
\text { calcis fractures through a lateral } \\
\text { approach in patients under } 40 \\
\text { years of age }\end{array}$ \\
\hline
\end{tabular}

Table 2: Meta-analysis studies done comparing operative vs conservative treatment for DIACFs

\begin{tabular}{cll}
\hline $\begin{array}{c}\text { SI. Meta-analysis studies } \\
\text { No. }\end{array}$ & $\begin{array}{l}\text { No. of studies } \\
\text { included }\end{array}$ & Conclusion \\
\hline 1. Bruce et $\mathrm{al}^{19} 2013$ & 4 & $\begin{array}{l}\text { No difference in functional ability and health related quality of } \\
\text { life after displaced intra-articular calcaneal fractures } \\
\text { High-risk of complications after surgery } \\
\text { High-incidence of subtalar arthrodesis after conservative } \\
\text { management }\end{array}$ \\
2. Jiang et $\mathrm{al}^{15} 2012$ & 10 & $\begin{array}{l}\text { Surgical treatment results in better restoration of anatomical } \\
\text { structures and thus functional recovery } \\
\text { High-risk of complications after surgery }\end{array}$ \\
3. Bajammal et al ${ }^{18} 2005$ & 4 & $\begin{array}{l}\text { Insufficient evidence whether operative is better than } \\
\text { nonoperative }\end{array}$ \\
4. Randle et al ${ }^{17} 2000$ & 6 & $\begin{array}{l}\text { Operatively treated patients had better outcomes with respect } \\
\text { to pain, return to work, heel width, gait abnormalities, and } \\
\text { radiographic outcomes, but none of these differences reached } \\
\text { statistical significance }\end{array}$ \\
\hline
\end{tabular}

outcomes with respect to pain, return to work, heel width, gait abnormalities, and radiographic outcomes, none of these differences were statistical significant. Later in 2005, Bajammal et $\mathrm{al}^{18}$ in their meta-analysis of $4 \mathrm{RCTs}$, also found insufficient literature evidence to prove any treatment method to be superior. Jiang et $\mathrm{al}^{15}$ published the largest meta-analysis study of 10 RCTs in 2012. Theirs is the only meta-analysis which shows better functional outcomes in operated DIACFs cases due to good anatomical reduction. However, the authors also found a higher complication rate in the operated cases, mostly due to the wound problems and infection. The latest meta-analysis is a Cochrane Review published was by Bruce and Sutherland in 2013. ${ }^{19}$ These authors included 4 RCTs in their study and found no difference in the functional ability and health related quality of life after displaced intra-articular calcaneal fractures, whether operated or managed conservatively. However, they reported a high-risk of complications after surgery and a high incidence of subtalar arthrodesis after conservative management. Out of 4 studies included in this review, one is a large study of 424 patients ${ }^{11}$ and has contributed to most of the outcomes of this meta-analysis, thus decreasing the value of this meta-analysis.

\section{DISCUSSION}

There is a lot of confusion surrounding the protocol of treatment for displaced intra-articular fractures. The current literature fails to provide any conclusive answer to the question-which is better, operation or conservative treatment. Various RCTs have reported different results, with some RCTs supporting the operative treatment of displaced fractures, ${ }^{7-10,20}$ while others show equivocal results ${ }^{11-14}$ when compared to nonoperative management.

The outcome after treatment of any calcaneal fracture can be assessed in two ways; the first is by comparing various outcome scores like VAS, SF-36 form, OM score or AOFAS score; and secondly by evaluating the complications associated with each treatment modality. 
Among the various functional outcome measures that have been used to assess the outcome of calcaneal fractures, prominent have been the VAS score and SF-36 form. The residual pain at rest and during weight bearing as measured by the VAS score was reported to be similar in both groups, operative and nonoperative, by Agren et al ${ }^{16}$ which was also confirmed later by Jiang et $\mathrm{al}^{15}$ in a meta-analysis and Bridgeman et $\mathrm{al}^{21}$ in a Cochrane report. However, subsequent investigators found better VAS scores in the operative group, but that was limited to only a certain cohort of patients like those who had congruent subtalar joint reduction or those not receiving Workman's compensation. ${ }^{11,12,22}$ The same contradictory findings come out when SF36 form was used for outcome assessment. In one study, Robb et $\mathrm{al}^{23}$ have reported a higher SF-36 score after operative management of DIACFs, whereas Buckley et $\mathrm{al}^{11}$ and Kennedy et $\mathrm{al}^{24}$ could not find any significant difference of SF-36 score between the two treatments modalities. In a RCT done by Agren et al, ${ }^{16}$ authors found similar SF36 scores at 1 year followup but higher scores at 12 years follow-up in the operated patients, although the difference was not significant $(p=0.06)$.

Bohlers' angle restoration along with anatomical reduction of the articular surface is considered one of the benefits and AIMS of surgical management of DIACFs. Anatomical reconstruction and Bohlers' angle are given importance in calcaneus fracture treatment by some authors because it is directly related to long-term complications like subtalar osteoarthritis, peroneal impingement, pain on weight bearing, etc. While some authors have reported improved functional results and reduced pain when anatomical reduction was done and Bohlers' angle restored, ${ }^{11,12,22}$ others have reported no association between the Bohler's angle and the final outcome. ${ }^{13,24}$ An important observation made by Buckley et a ${ }^{11}$ is that when fractures with less comminution (Sanders type II) were operated, their SF-36 scorings were 2.74 times more likely to be above mean value. On the other hand, no such difference was noted in more comminuted fractures (Sanders type IV), whether treated operatively or conservatively. The authors have pointed out that low energy trauma fractures are easier to fix and well-reduced.

Complications occurring after treatment of DIACFs are a significant cause of morbidity, and occur in both types of treatment modalities. Various complications that commonly occur include poor wound healing, infection, persistent pain, compartment syndrome, deep venous thrombosis, peroneal tendon problems, etc. which often require operative management in the form of arthrodesis, fasciotomies, ostectomies, debridement and possibly implant removal. Many authors in the past have reported complications with ORIF of calcaneal fractures ${ }^{25-27}$ but a RCT comparing the complication rates between operated and nonoperated DIACFs was done by Howard et $\mathrm{al}^{7}$ in 2003. Among the operatively treated group, the authors reported major complications in $25 \%$ fractures which included superficial wound slough, deep infection and malposition of fixation as most common ones. On the other hand $16 \%$ of conservatively managed fractures developed complications, needing subsequent arthrodesis due to subtalar joint arthritis. According to the authors, there is no significant difference between in SF-36 and VAS scores when ORIF-managed cases with/without complications were compared to non-operatively managed cases without complications. Their outcome is equal to or better than nonoperatively managed cases with complications. Various studies have also identified the experience of the treating surgeon as an important factor affecting the outcome of calcaneal fractures, better outcome with a senior experienced operating surgeon. $5,7,28$

In spite of the above mentioned RCTs done to compare operative and nonoperative management of DIACFs, no conclusive proof emerges proving the superiority of one treatment method over another. What significantly increases the confusion in an already clouded stage is that the metaanalyses done on this topic have also shown different results (see Table 2). The earliest meta-analysis comparing operative and conservative treatments in DIACFs was done by Randle et $\mathrm{a}^{17}$ who observed slightly better outcomes in operated DIACFs in terms of pain, return to work, heel width, gait abnormalities and radiographic outcomes; however the difference was not statistically significant. Bajammal et $\mathrm{al}^{18}$ in 2005 , also pointed out that there was insufficient evidence to prove any treatment modality to be better than the other. In 2012, Jiang et a ${ }^{15}$ analyzed various RCTs and CCTs done till that time; the authors noted that surgical treatment gives better restoration of anatomical structures and eventually better functional recovery, but is also associated with a higher risk of complications. In a more recent review of trials in the Cochrane library, ${ }^{19}$ no significant difference was found in functional ability and health related quality of life between operative $v s$ conservative management of DIACFs at 3 years follow-up. Additionally the authors noted a higher risk of major complications after surgery, and a high incidence of subtalar arthrodesis after conservative management. ${ }^{19}$

A point well noted by Jiang et $\mathrm{a}^{15}$ in their meta-analysis was that all the RCTs done prior to their analysis had clubbed the open calcaneus cases with closed fractures while evaluating the outcomes and complications. This point becomes important due to the fact that open fractures are more prone to wound healing complications and have less patient satisfaction rates, which might have caused some bias in overall results. Another limitation that we observed was that none 
of the studies collected information regarding the habitus, body-mass index and smoking status of the patients, which might also affect the healing capacity of wounds and fractures.

Today, although the RCTs and meta-analysis do not unanimously prove one method superior over another, but some important conclusions can be drawn. Operated DIACFs have better restoration of anatomy and Bohler's angle and lesser rates of subtalar arthritis and arthrodesis, but are associated with more wound healing problems. Nonoperative management has the advantage of similar functional outcome while avoiding complications related to surgery, but has more rate of reoperation due to subtalar arthritis and has long-term morbidity due to varus and wide heel. Surgeon experience, institute workload relating to incidence of calcaneus fracture, soft tissue -injuries and open fractures, as well as associated injuries in polytrauma cases all influence outcomes. A major factor in underdeveloped countries is treatment delays, which none of the above studies considers, as this is unique to areas where overcrowding is prevalent and surgical delays may not be in the hands of the patient or the surgeon.

\section{CONCLUSION}

A cursory look at the available RCTs and meta-analyses, seemingly shows that operatively and nonoperatively managed DIACFs have similar functional outcomes; however, on stratification of groups, the literature reveals better functional results in the operated patients who do not develop a complication, but poorer outcomes in patients with more severe injury patterns (higher Sanders' Type). Complications were associated with both groups, but were slightly higher in the operated group (probably due to open cases inclusion); nevertheless the difference was not significant. Despite the plethora of publications, even today there is a need for larger randomized trials to address this question and bring out a conclusive answer. What we can conclude is that if the surgeon and the hospital have the experience and the facility, and case selection is done diligently so that complications are avoided, surgical intervention maybe a better option. On the other hand if the above conditions are not met, and the soft tissues are disrupted, with extreme comminution, nonoperative treatment or interventions other than the extensile approach maybe appropriate, with an understanding that subsequent surgery to manage complications maybe needed.

\section{REFERENCES}

1. Lindsay WR, Dewar FP. Fractures of the os calcis. Am J Surg. PubMed PMID:13521162. 1958;95(4):555-576.
2. Pozo JL, Kirwan EO, Jackson AM. The long-term results of conservative management of severely displaced fractures of the calcaneus. J Bone Joint Surg Br 1984 May;66(3):386-390.

3. Hammesfahr JF. Surgical treatment of calcaneal fractures. Orthop Clin North Am 1989;20(4):679-689.

4. Leung KS, Yuen KM, Chan WS. Operative treatment of displaced intra-articular fractures of the calcaneum. Medium-term results. J Bone Joint Surg Br 1993;75(2):196-201.

5. Sanders R. Intra-articular fractures of the calcaneus: present state of the art. J Orthop Trauma 1992;6(2):252-265.

6. Stephenson JR. Displaced fractures of the os calcis involving the subtalar joint: the key role of the superomedial fragment. Foot and Ankle 1983 Sep-Oct;4(2):91-101.

7. Howard JL, Buckley R, McCormack R, et al. Complications following management of displaced intra-articular calcaneal fractures: a prospective randomized trial comparing open reduction internal fixation with nonoperative management. J Orthop Trauma 2003 Apr;17(4):241-249.

8. Nouraei MH, Moosa FM. Operative compared to nonoperative treatment of displaced intra-articular calcaneal fractures. J Res Med Sci: the official journal of Isfahan University of Medical Sciences. 2011 Aug; 16(8):1014-1019.

9. O'Farrell DA, O'Byrne JM, McCabe JP, et al. Fractures of the os calcis: improved results with internal fixation. Injury 1993 Apr;24(4):263-265.

10. Thordarson DB, Krieger LE. Operative vs nonoperative treatment of intra-articular fractures of the calcaneus: a prospective randomized trial. Foot Ankle Int 1996 Jan;17(1):2-9.

11. Buckley R, Tough S, McCormack R, et al. Operative compared with nonoperative treatment of displaced intra-articular calcaneal fractures: a prospective, randomized, controlled multicenter trial. J Bone Joint Surg Am 2002 Oct;84-A(10):1733-1744.

12. Dooley P, Buckley R, Tough S, et al. Bilateral calcaneal fractures: operative versus nonoperative treatment. Foot Ankle Int 2004 Feb;25(2):47-52.

13. Ibrahim T, Rowsell M, Rennie W, et al. Displaced intra-articular calcaneal fractures: 15-year follow-up of a randomised controlled trial of conservative versus operative treatment. Injury $2007 \mathrm{Jul} ; 38(7): 848-855$.

14. Parmar HV, Triffitt PD, Gregg PJ. Intra-articular fractures of the calcaneum treated operatively or conservatively. A prospective study. Bone Joint Surg Br 1993 Nov;75(6):932-937.

15. Jiang N, Lin QR, Diao XC, et al. Surgical versus nonsurgical treatment of displaced intra-articular calcaneal fracture: a meta-analysis of current evidence base. Int Orthop 2012 Aug; 36(8):1615-1622.

16. Agren PH, Wretenberg P, Sayed-Noor AS. Operative versus nonoperative treatment of displaced intra-articular calcaneal fractures: a prospective, randomized, controlled multicenter trial. J Bone Joint Surg Am 2013 Aug 7;95(15):1351-1357.

17. Randle JA, Kreder HJ, Stephen D, et al. Should calcaneal fractures be treated surgically? A meta-analysis. Clin Orthop Related Res $2000 \operatorname{Aug}(377): 217-227$.

18. Bajammal S, Tornetta P, 3rd, Sanders D, et al. Displaced intraarticular calcaneal fractures. J Orthop Trauma 2005 May-Jun; 19(5):360-364.

19. Bruce J, Sutherland A. Surgical versus conservative interventions for displaced intra-articular calcaneal fractures. The Cochrane Database of Systematic Reviews. 2013;1:CD008628.

20. Stephens MM. Operative vs. nonoperative treatment of intraarticular fractures of the calcaneus: a prospective randomized trial. Foot Ankle Int 1996 Oct;17(10):653. 
21. Bridgman SA, Dunn KM, McBride DJ, et al. Interventions for treating calcaneal fractures. The Cochrane Database of Systematic Reviews. 2000 (2):CD001161.

22. Basile A. Operative versus nonoperative treatment of displaced intra-articular calcaneal fractures in elderly patients. J Foot Ankle Surg 2010 Jan-Feb;49(1):25-32.

23. Robb CA, Deans V, Iqbal MJ, et al. Comparison of nonoperative and surgical treatment of displaced calcaneal fractures. Foot 2007;17(4):169-173.

24. Kennedy JG, Jan WM, McGuinness AJ, et al. An outcomes assessment of intra-articular calcaneal fractures, using patient and physician's assessment profiles. Injury 2003 Dec;34(12): 932-936.
25. Abidi NA, Dhawan S, Gruen GS, et al. Wound-healing risk factors after open reduction and internal fixation of calcaneal fractures. Foot Ankle Int 1998 Dec;19(12):856-861.

26. Al-Mudhaffar M, Prasad CV, Mofidi A. Wound complications following operative fixation of calcaneal fractures. Injury 2000 Jul;31(6):461-464.

27. Harvey EJ, Grujic L, Early JS, et al. Morbidity associated with ORIF of intra-articular calcaneus fractures using a lateral approach. Foot Ankle Int 2001 Nov;22(11):868-873.

28. Sanders R, Fortin P, DiPasquale T, et al. Operative treatment in 120 displaced intraarticular calcaneal fractures. Results using a prognostic computed tomography scan classification. Clin Orthop Related Res 1993 May(290):87-95. 